\title{
Retinoblastoma-Like Protein 1
}

National Cancer Institute

\section{Source}

National Cancer Institute. Retinoblastoma-Like Protein 1. NCI Thesaurus. Code C91748.

Retinoblastoma-like protein 1 (1068 aa, $\sim 121 \mathrm{kDa}$ ) is encoded by the human RBL1 gene.

This protein plays a role in the progression of the cell cycle. 